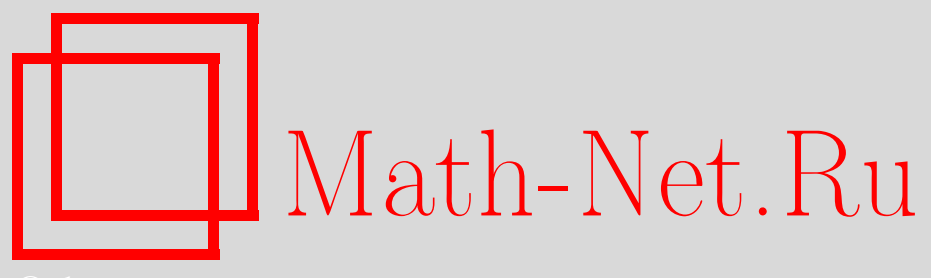

С. С. Гончаров, Ю. Л. Ершов, В. М. Левчук, В. Д. Мазуров, В. И. Сенашов, А. И. Созутов, Н. С. Черников, Владимир Петрович Шунков (некролог), УМН, 2013, том 68, выпуск 4, 177-178

DOI: https://doi.org/10.4213/rm9542

Использование Общероссийского математического портала Math-Net.Ru подразумевает, что вы прочитали и согласны с пользовательским соглашением http: //www. mathnet.ru/rus/agreement

Параметры загрузки:

IP : 35.173 .137 .237

26 апреля 2023 г., 12:03:55

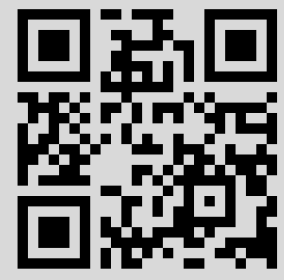




\section{Владимир Петрович Шунков}

29 июля 2012 г. исполнилось 80 лет со дня рождения Владимира Петровича Шункова - выдающегося ученого, многолетнего лидера Красноярской алгебраической школы, награжденного в 1999 г. медалью ордена "За заслуги перед Отечеством". Незадолго до юбилея, 3 октября 2011 г., его сердце остановилось.

Владимир Петрович родился в селе Бура Читинской области в семье крестьянина, потомка забайкальских казаков. Ему везло с учителями. Еще в школе из университетского учебника Л. А. Окунева он узнал о теории групп. В Пермском университете его курсовой работой руководил молодой кандидат наук М.И. Каргаполов, позднее ставший членом-корреспондентом $\mathrm{AH}$ CССР. Руководитель дипломной работы В. П. Шункова (1959 г.) профессор С. Н. Черников пригласил его в аспирантуру. По распределению Владимир Петрович работал два года в вузах Челябинска, а аспирантуру завершил в отделе теории групп Свердловского отделения МИ АН СССР. Защитив в 1965 г. кандидатскую дис-

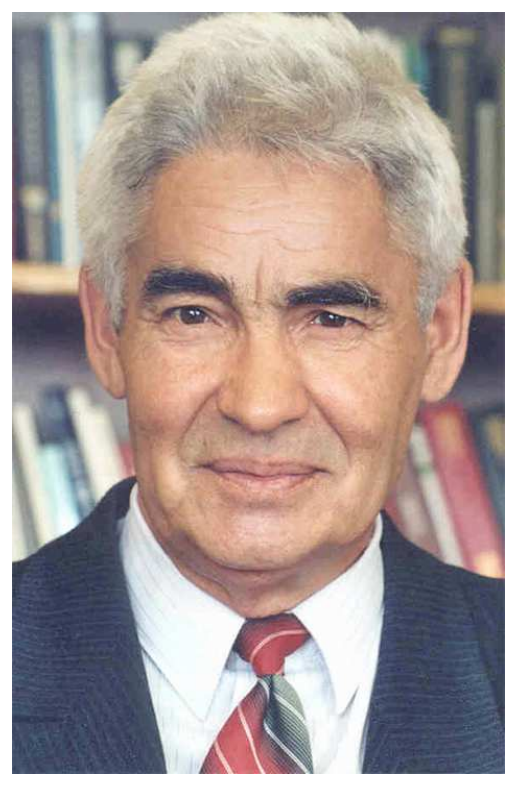
сертацию, он по приглашению академика Л. В. Киренского переезжает в Красноярск, навсегда связав свою жизнь с формировавшимися филиалом СО АН СССР и Красноярским университетом.

Первую статью Владимир Петрович опубликовал в 1964 г. в Докладах АН СССР; в течение следующих четырех лет он там же публикует серию из пяти работ. Известность и признание ему принесли, прежде всего, достижения в теории бесконечных групп. В период 1967-1972 гг. В. П. Шунков разрабатывает основы нового направления исследований периодических и смешанных групп с условиями конечности, ослабляющими локальную конечность. За основу берется свойство конечности подгрупп, порождаемых парой инволюций - элементов порядка два. В 1937 г. локальную конечность 2-групп с таким свойством и некоторым дополнительным условием минимальности установил О.Ю. Шмидт, обративший внимание на необходимость обобщения классической теоремы Фробениуса.

В 1970 г. Владимир Петрович решает две ключевые проблемы минимальности в классе локально конечных групп. В следующие два года им обобщена теорема Фробениуса и завершена работа над проблемами минимальности С. Н. Черникова. В 1972 г. В. П. Шунков доказывает свою знаменитую теорему о почти разрешимости и локальной конечности периодической группы с почти регулярной инволюцией. В феврале 1973 г. он защищает докторскую диссертацию "О некоторых вопросах теории локально конечных групп". Примечательно, что ее основные результаты в том же году были отражены в вышедшей за рубежом монографии О. Кегеля и Б. Верфрица [1].

DOI: $10.4213 / \mathrm{rm} 9542$ 
Красноярская алгебро-логическая научная школа, соединяющая академические и университетские исследования, родилась по инициативе академика А. И. Мальцева. У ее истоков стояли В. М. Бусаркин - первый заведующий кафедрой алгебры и математической логики Красноярского государственного университета и Ю. М. Горчаков первый в Красноярске доктор математик, возглавлявший с 1964 г. в Институте физики СО АН СССР математическую лабораторию, а после ее деления в 1967 г. - лабораторию алгебры и математической логики. Уже в 1974 г. защитили кандидатские диссертации их первые ученики. С конца 1960-х годов начал работать объединенный алгебраический семинар Красноярска.

В. П. Шунков возглавил лабораторию, когда переход В. М. Бусаркина в Красноярский политехнический институт в 1972 г. и отъезд из Красноярска Ю. М. Горчакова в 1973 г. заметно снизили активность школы. На открытии красноярского Вычислительного центра СО АН СССР, когда решался вопрос о переводе В.П. Шункова в КВЦ, академик Г. И. Марчук даже удивился, что у Владимира Петровича нет учеников.

Работать с учениками он стал с 1974 г., но наиболее интенсивно - после приглашения его в 1975 г. в университет на должность заведующего кафедрой и активизации работы красноярского алгебраического семинара. Под руководством В.П. Шункова выросли 25 кандидатов и 6 докторов наук. Вместе с учениками он разработал большие фрагменты “положительной” теории периодических групп.

В развитие направления групп с условиями конечности им был выделен ряд классов групп (некоторые сейчас носят его имя), промежуточных между классами локально конечных и периодических групп. Теоремы Шункова находят связи с различными глубокими проблемами; ярко это иллюстрирует статья [2]. В 1990 г. Владимир Петрович написал первую монографию [3], а всего опубликовал (один или с учениками) 5 монографий и свыше 150 статей.

Значительную часть своих работ В. П. Шунков опубликовал в журнале “Алгебра и логика". За активное участие в работе одноименного семинара он в числе первых был награжден серебряным значком. Ему присуждалась государственная стипендия для выдающихся ученых России, а в 1994 г. Владимир Петрович стал лауреатом премии имени А. И. Мальцева РАН.

Несомненна заслуга Владимира Петровича в том, что с 70-х годов прошлого века в Красноярске стали проводиться всесоюзные и всероссийские конференции, симпозиумы, школы, а с 90-х годов - международные конференции. Его 80-летию и памяти посвящены Мальцевские чтения в Новосибирске (ноябрь 2012 г.) и очередная международная конференция "Алгебра и логика: теория и приложения" (Красноярск, июль 2013 г.).

С. С. Гончаров, Ю. Л. Ершов, В. М. Левчук, В.Д. Мазуров, В.И. Сенашов, А.И. Созутов, Н.С. Черников

\section{Список литературы}

[1] O. H. Kegel, B. A. F. Wehrfritz, Locally finite groups, North-Holland Math. Library, 3, North-Holland Publishing Co., Amsterdam-London; American Elsevier Publishing Co., Inc., New York, 1973, xi+210 pp.

[2] С. И. Адян, "Еще раз о периодических произведениях и проблеме А. И. Мальцева", Матем. заметки, 88:6 (2010), 803-810; англ. пер.: S. I. Adyan, "Once more on periodic products of groups and on a problem of A. I. Maltsev", Math. Notes, 88:5-6 (2010), 771-775.

[3] В. П. Шунков, $M_{p}$-группь, Наука, М., 1990, 160 с. 